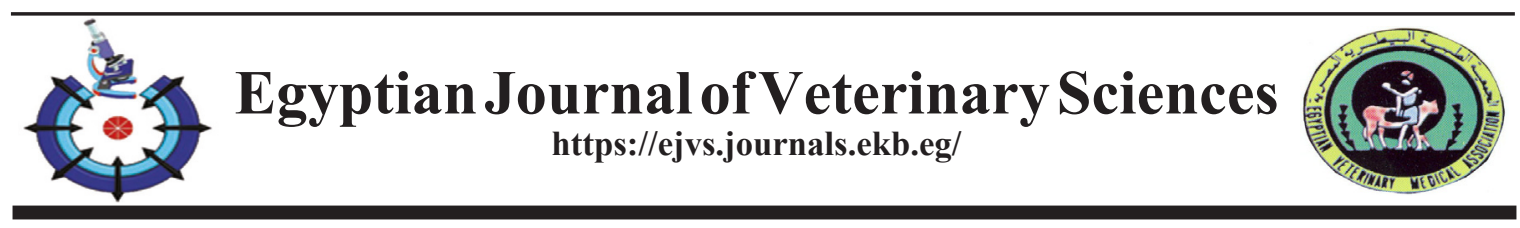

\title{
Role of Changes in Physical and Chemical Properties of Milk in Determination of Lambing in Ewes
}

\author{
Hussam M. Alimam¹, Uday T. Naoman ${ }^{2}$, Elias K. Hussein ${ }^{2}$, Mohammad O. Dahl ${ }^{1}$ \\ ${ }^{1}$ Department of Internal and Preventive Medicine, College of Veterinary Medicine, \\ University of Mosul, Mosul, 41002, IRAQ. \\ ${ }^{2}$ Department of Surgery and Theriogenology, College of Veterinary Medicine, \\ University of Mosul, Mosul, 41002, IRAQ.
}

\begin{abstract}
M AMMARY gland and its secretion around parturition show different changes. The objective of the study conducted here was to examine the changes in the physical and chemical properties of the milk before, during, and after lambing. A total of 40 local Iraqi breed ewes, 2 to 4 years-old, confirmed pregnant by B-mode ultrasonography was used in this study. Milk was collected from each study ewe at 3 consecutive times, (i) on day 135 of pregnancy, (ii) at the time of lambing, and (iii) on day 5 postpartum. Milk examinations included colour, consistency, density, specific gravity, chloride contents, $\mathrm{pH}$, light transmittance percentage, and light extinction coefficient. Results indicated changes of colour and consistency during different study periods. Milk density and specific gravity decreased as ewes approached lambing time and started lactation. Milk pH was low at the time of lambing. Mean of light transmittance percentage became zero at the time of lambing and later. The light extinction coefficient increased at the time of lambing and later. In conclusion, although signs of parturition could be simply observed, changes in milk properties can prompt owners to closely observe ewes whether they have already lambed or not.
\end{abstract}

Keywords: Milk, ewes, parturition, lambing.

\section{Introduction}

Mammary gland around parturition time shows different changes as a function of dramatic physiological adaptations of the animal for the transition period; from late pregnancy to lactation [1-3]. Mammary secretion undergoes a sequence of changes in ewes close to lambing [4]. Indeed, the milk secreted during this period is identified as transit milk, which is characterized by the formation of the colostrum that is subsequently changed to mature milk $[5,6]$. Ruminant colostrum is a thick creamy yellowish colour with a mixture of lacteal secretion containing immunoglobulins and other serum proteins, vitamins, lactoferrin, fat, and minerals $[7,8]$.
Determining the time of parturition is important for handling pregnant animals failed to show signs of parturition or suffered from dystocia $[9,10]$. Although the normal pregnancy period in ewes is about 140-155 days, with some individual variation according to the breed [11], different methods can be used for determination of the onset of parturition, including breeding records, ultrasonography, hormonal profile, specific proteins, changes in animal behaviour, as well as changes in the mammary gland (wet/dry udder) [12]. Lambing in some ewes, however, could be potentially missed by the owners as flocks of sheep are generally grazed in open areas where animals usually are not frequently closely

Corresponding author: Mohammad O. Dahl, E-mail:mdahl@uomosul.edu.iq, Tel: +9647710404737

(Received 28/08/2021; accepted 23/09/2021)

DOI. 10.21608/ejvs.2021.93069.1273

(C2021 National Information and Documentation Center (NIDOC) 
observed. Therefore, changes in the physical and chemical properties in mammary secretion could prompt the owners and veterinarians to closely observe ewes around lambing time.

Although mammary secretion was daily investigated around lambing [4], only amount, colour, and viscosity of the secretion have been observed. Different properties of milk have not been investigated. For instance, milk $\mathrm{pH}$ has not been evaluated around parturition. In addition, the spectrophotometric characteristics of the milkwere notestimated using fresh ewes' milk, although the light transmittance percentage was estimated using powder or packed milk samples [13]. Therefore, the objective of the study conducted here was to examine the changes in the physical and chemical properties of the milk before, during, and after parturition.

\section{Materials and Methods}

\section{Study Population}

Awasi sheep, the local-Iraqi-breed, from one herd located in Bartella discrete, Mosul city were considered for inclusion in this study. The flock was selected because the owner was willing to participate in the study. In this herd, sheep were fed on 1.5 to $2 \mathrm{~kg}$ per a day mixture ration, mainly hay and barley, during the entire period of the study, and grazed 6-8 hours daily on pasture, with water provided freely at all times. Oestrusfor all ewes was synchronized by Intra-vaginal sponge impregnated by progesterone (Synncropart 40 mg sheep sponge; Ceva Sante Animal, France) for 12 days. Later, ewes showed oestrus signs were naturally mated by proven fertile rams.

\section{Study Ewes}

A total of 40 ewes, 2 to 4 years-old, confirmed pregnant by B-mode ultrasonography, was used in this study. Health status of study ewes was routinely observed, and the pregnancy condition was monthly examined. No medication was administered to study ewes until lambing. Time of lambing was clinically diagnosed by observing signs of parturition such as protrusion of the fetal membrane, or detecting dilatation of the cervix during vaginal examination.

\section{Milk Sampling}

A total of $10 \mathrm{~mL}$ milk was collected using sterilized cups from each study ewe at 3 consecutive times, (i) on day 135 of pregnancy, (ii) at the time of lambing, and (iii) on day 5 postpartum. The purpose of selecting these days was to followup milk transit period and colostrum formation. A daily milk sampling in the days prior to lambing was not considered because it might adversely affect the quality of the colostrum.

\section{Visual and Laboratory Examination}

After the collection, a visual examination of the colour and consistency of the milk was performed, and then the milk samples were kept in a cooled box and transferred to the diagnostic laboratory. Chemical examination ofthe milk samples included (i) milk density, which was measured via dividing the sample weight by its volume; (ii) specific gravity, which was measured via dividing the sample weight by same volume of normal saline with temperature at $28{ }^{\circ} \mathrm{C}$; (iii) chloride contents using sliver nitrate and potassium chromate solutions as previously described [14-16] where the yellow colour indicates existence of $>0.14 \%$ chloride, which is considered abnormal; and (iv) milk pH, which wasdirectly measuredafter collection of samples using a pH meter ( $\mathrm{pH} 211$ Microprocessor $\mathrm{pH}$ meter, Hanna Instruments, Portugal). On the other hand, the spectrophotometric characteristics of the milk were indicated via measuring (i) the light transmittance percentage of the samples, and (ii) the light extinction coefficient of the samples. Both measurements were performed using a spectrophotometer (Spectrodirect, Lovibond Inc., Germany)

\section{Statistical Analysis}

In this study, analysis of variance (ANOVA) repeated measures was used to compare the variables for milk density, specific gravity, milk $\mathrm{pH}$, light transmittance percentage, and light extinction coefficient over different times of the study, i.e., day 135 of pregnancy, time of lambing, and day 5 postpartum [17]. Comparisons between different times were achieved by pairwise comparisons of marginal linear predictions [18]. In this analysis, a value of $\mathrm{P} \leq 0.05$ (2-tailed) was considered significant. Results were reported as mean \pm standard deviation. The statistical analysis was performed using STATA 13.0 (StataCorp, College Station, TX).

\section{Results}

Visual examination indicated that the colour and consistency of the milk changed from yellowish gel to yellowish-white thick to white thin on day 135 of pregnancy, at the time of lambing, and on day 5 postpartum, respectively (Fig. 1). Milk density and specific gravity decreased $(\mathrm{P}<0.05)$ as ewes approached lambing 
time and started lactation (Fig. 2). Milk chloride contents was $>0.14 \%$ in all study times. In addition, milk pH was low $(\mathrm{P}<0.05)$ at the time of lambing compared to day 135 of pregnancy and day 5 postpartum, without significant difference between milk $\mathrm{pH}$ at day 135 of pregnancy and day 5 postpartum (Fig. 3). Mean of light transmittance percentage was 2.64 at day
135 of pregnancy, whereas it became zero at the time of lambing and later (Fig. 4). On the other hand, the light extinction coefficient increased $(\mathrm{P}$ $<0.05)$ at the time of lambing and later compared to day 135 of pregnancy, without differences between its mean at the time of lambing and day 5 postpartum (Fig. 4).

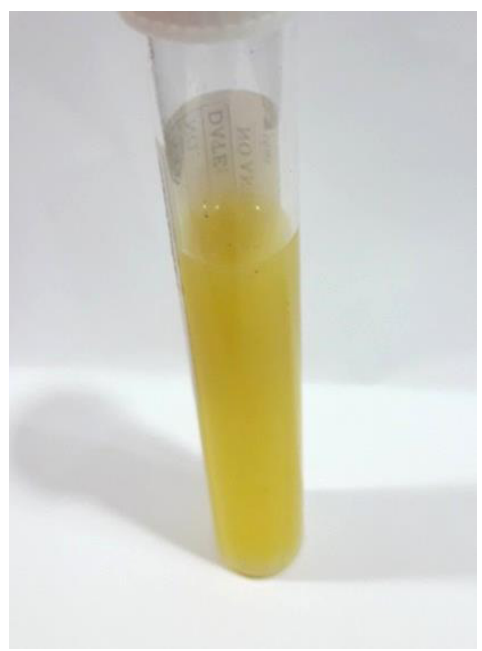

A

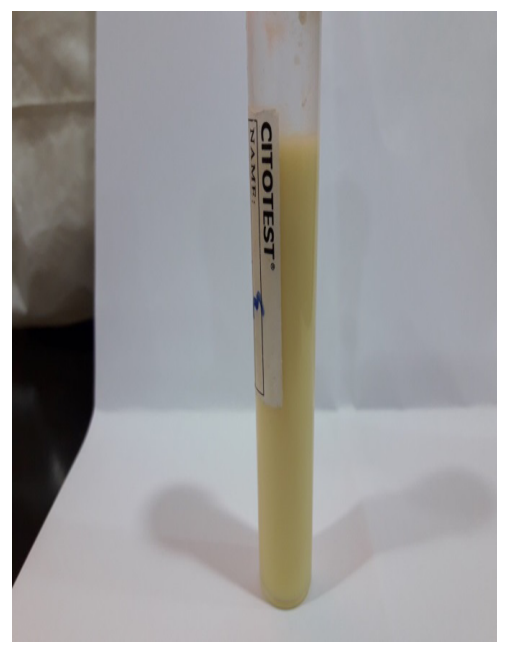

B

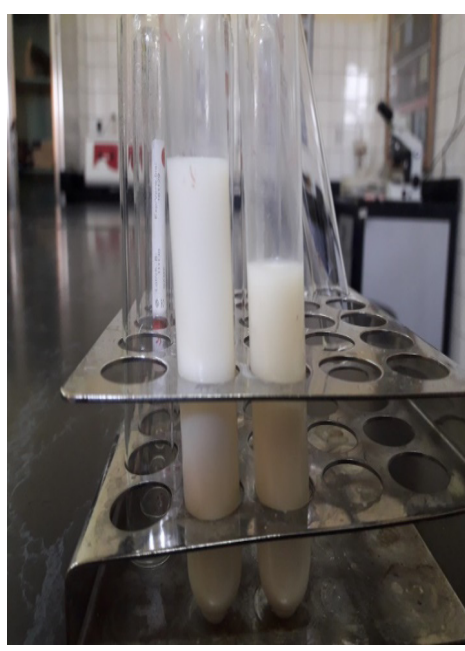

$\mathrm{C}$

Fig. 1. Colour and consistency of the milk collected from study ewes: (A) on day 135 of pregnancy; (B) at the time of lambing; and (C) on day 5 postpartum.

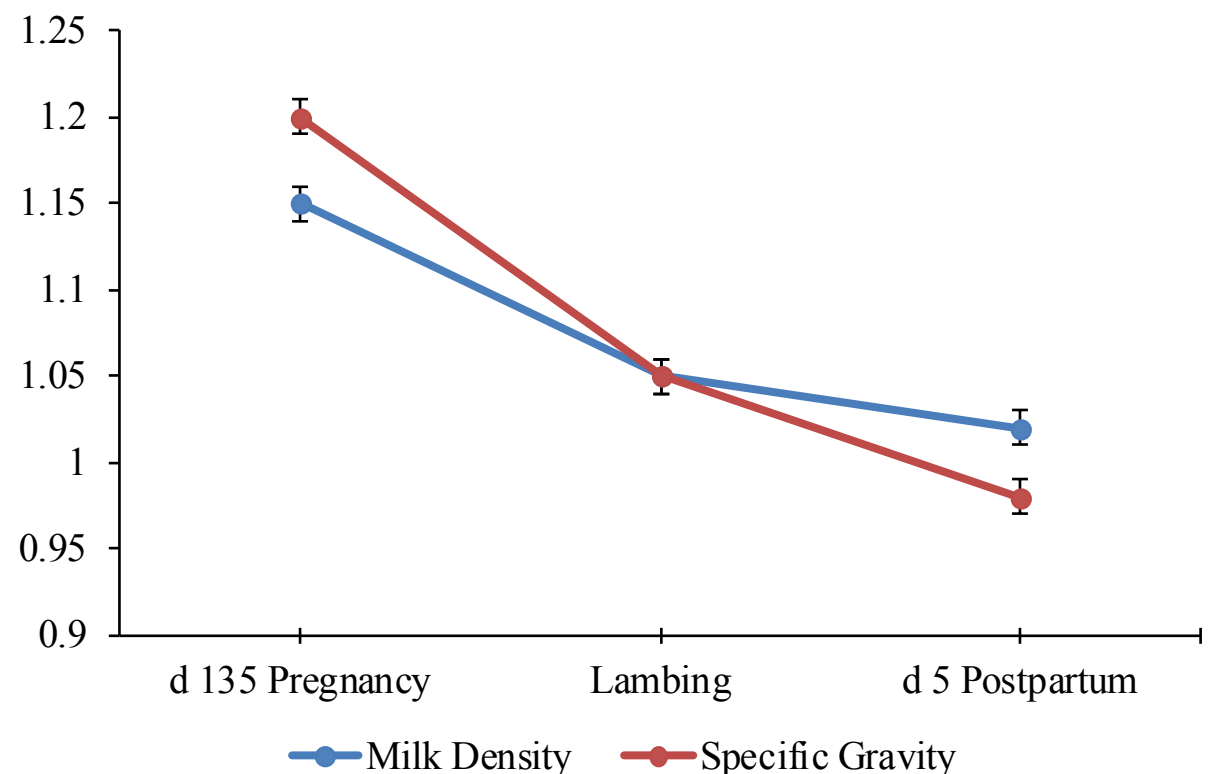

Fig. 2. Changes in milk density and specific gravity during study times. 


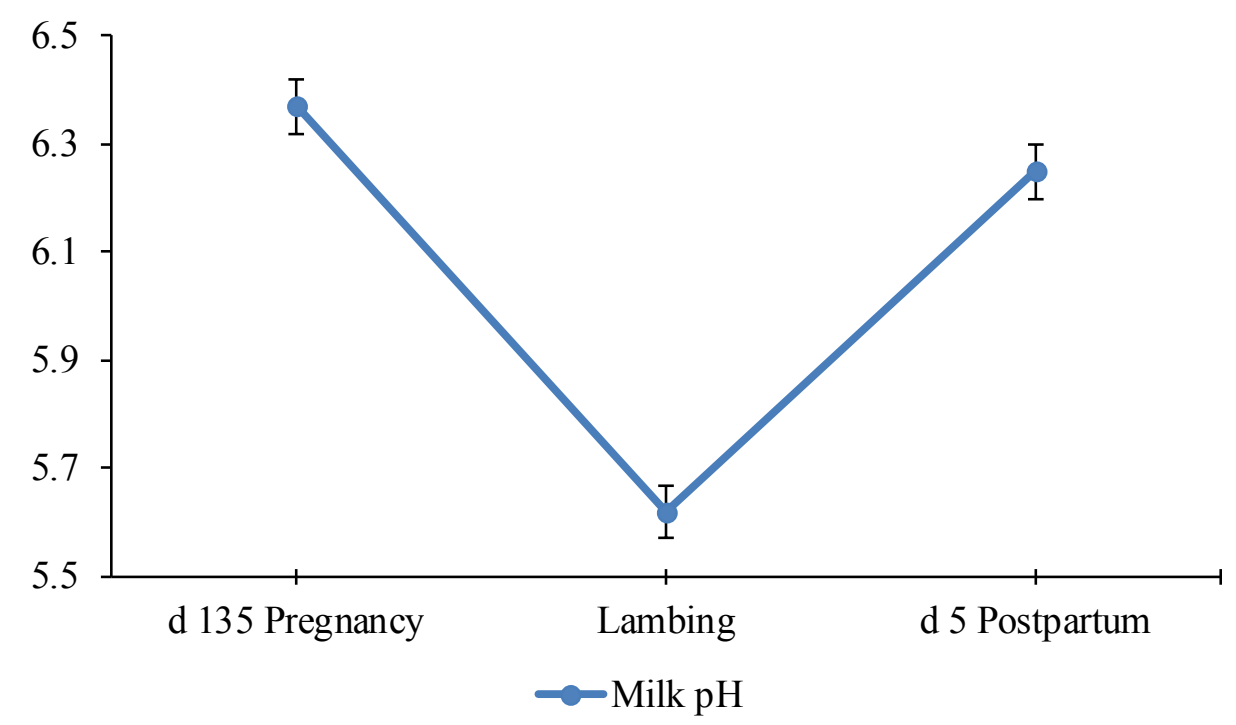

Fig. 3. Drop of milk pH at the time of lambing compared to day 135 of pregnancy and day 5 postpartum.

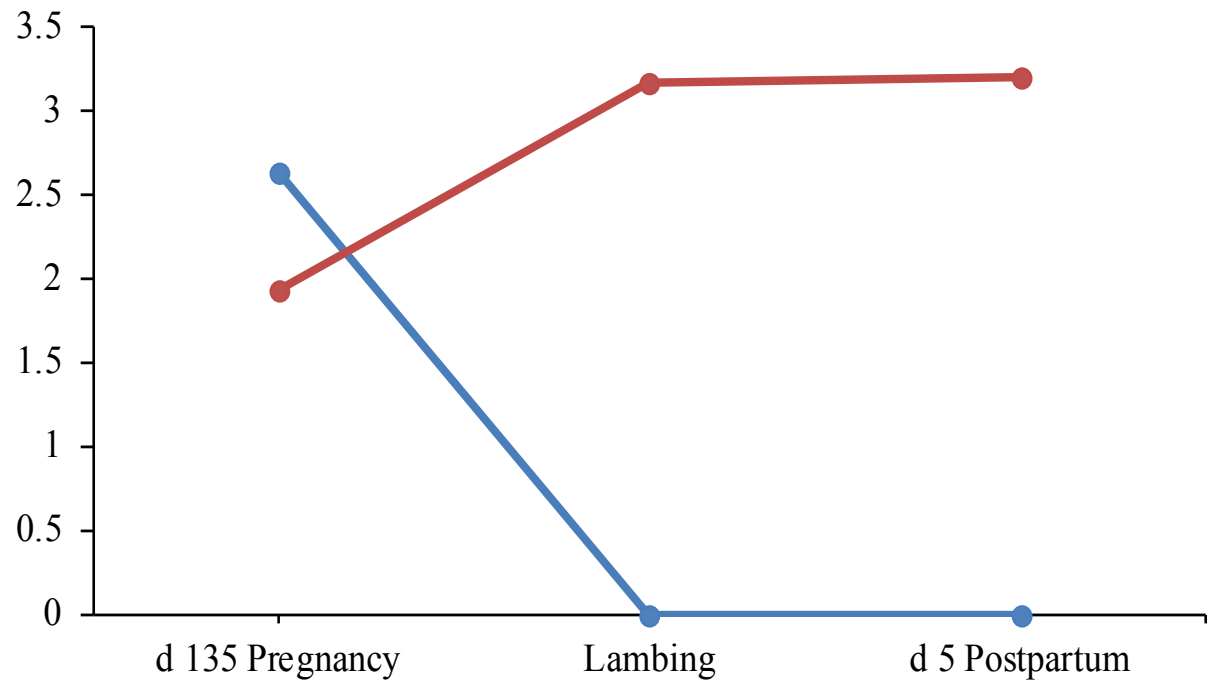

$\rightarrow$ Light transmittance percentage $\rightarrow$ Light extinction coefficient

Fig. 4. Changes in spectrophotometric characteristics of milk (milk light extinction coefficient and light transmittance percentage) collected from the study ewes.

\section{Discussion}

The current study was conducted to examine the changes in the physical and chemical properties of the milk before, during, and after parturition. Results showed that the colour and consistency of milk were different during the periods of the study. These differences are attributed to the dramatic physiological adaptations of the mammary gland during the transition from late pregnancy to lactation as a function of hormonal changes in the animal body [2,3]. This result is in line with the study of Boucher [19] who indicated that the transit period shows significant changes in milk consistency as a function of colostrum secretion and the presence of immunoglobulin and other milk components.

In this study, milk density and specific gravity decreased as ewes approached lambing time 
and started lactation. A potential reason is that immunoglobulins have less weight and more fluidity compared to proteins and epithelial cells forming the colostrum, and the specific gravity is correlated to the total protein concentration rather than immunoglobulins [20]. Results of our study were in line with the study of Sahan et al. [21], who reported that the absolute density/gravity after birth was $1.04 \mathrm{~g} / \mathrm{ml}$.

Milk chloride contents were stable at all study times. A previous study reported similar milk chloride contents in the same sheep species used in the current study [16].Changes in chloride contents in the milk are considered a good indicator for mammary gland health and subclinical mastitis, as tight junction cells and mammary cell membranes are disrupted as a function of the inflammatory process, resulting in opening the paracellular routes and hence the influx of blood contents including chloride into the mammary gland $[15,16]$.

In this study, milk $\mathrm{pH}$ did not differ at day 135 of pregnancy and day 5 postpartum, while it was low at the time of lambing. Changes in milk contents including protein, vitamins, antibodies, and other milk components during milking time could be attributed to the observed changes in milk $\mathrm{pH}$ in the study animals. Results of this study agree with other studies [21, 22], who reported milk pH at 6.72 after birth in Awassi ewes. In addition, the current study indicated that the light transmittance percentage became zero at the time of lambing and later. Presence of milk fat globule emulsion can interact with light transmission [23-25]. No study has estimated the light transmittance percentage using fresh ewes' milk. However, a former study estimated the light transmittance percentage in powder or packed milk samples [13], which are incomparable with the sample of the current study. On the other hand, the light extinction coefficient increased at the time of lambing and later, compared to day 135 of pregnancy. Amounts of milk components such as vitamins and proteins at parturition and later can affect light transmission.

\section{Conclusions}

Different physical and chemical changes in the milk can be observed around lambing time. Although signs of parturition could be simply observed, physical changes in milk properties can prompt owners to closely observe ewes whether they have already lambed or not.

\section{Conflicts of Interest}

The authors declare that there are no conflicts of interest.

\section{Funding Statement}

The authors received no specific funding for this work.

\section{Acknowledgment}

The authors thank the College of Veterinary Medicine, University of Mosul, for supporting this work, and the animals' owner participated in the study.

\section{References}

1. Neville, T. L., Meyer, A. M., Reyaz, A., Borowicz, P. B., Redmer, D. A., Reynolds, L. P., Caton, J. S., and Vonnahme, K. A. Mammary gland growth and vascularity at parturition and during lactation in primiparous ewes fed differing levels of selenium and nutritional plane during gestation. Journal of Animal Science and Biotechnology, 4(1), 6 (2013). . https://doi.org/10.1186/2049-1891-4-6

2. Lérias, J. R., Hernández-Castellano, L. E., SuárezTrujillo, A., Castro, N., Pourlis, A., and Almeida, A. M. The mammary gland in small ruminants: major morphological and functional events underlying milk production--a review. The Journal of Dairy Research, 81(3), 304-318(2014).https:// doi.org/10.1017/S0022029914000235

3. Paten, A.M., Duncan, E.J., and Pain, S.J. Functional development of the adult ovine mammary glandinsights from gene expression profiling. $B M C$ Genomics, 16, 748 (2015). https://doi.org/10.1186/ s12864-015-1947-9

4. McCance, I., and G. Alexander. The onset of lactation in the merino ewe and its modification by nutritional factors.Australian Journal of Agricultural Research, 10, (5), 699-719(1959).

5. Hart, K. W., Contou, C., Blackberry, M., and Blache, D. Merino ewes divergently selected for calm temperament have a greater concentration of immunoglobulin $\mathrm{G}$ in their colostrum than nervous ewes. Proceedings of the Advancement of Animal Breeding and Genetics, 18, 576-579(2009).http:// livestocklibrary.com.au/handle/1234/6128

6. Yilmaz, O., and Kasikci, G. Factors affecting colostrum quality of ewes and immunostimulation. Turkish Journal of Veterinary and Animal Sciences, 37, 390-394 (2013). 
7. Boland, T. M., Brophy, P. O., Callan, J. J., Quinn, P. J., Nowakowski, P., and Crosby, T. F. The effect of mineral supplementation to ewes in late pregnancy on colostrum yield and immunoglobulin $\mathrm{G}$ absorption in their lambs. Livestock Production Science, 97(2-3), 141-150(2005).https://doi. org/10.1016/j.livprodsci.2005.03.004

8. Castro, N., Capote, J., Bruckmaier, R. M., \& Arguello, A. Management effect on colostrogenesis in small ruminants: a review. Journal of Applied Animal Research, 39(2),85-93(2011).https://doi.or $\mathrm{g} / 10.1080 / 09712119.2011 .581625$

9. Bearden, H.J., Fuguay, J.W., and Willard, S. T. Applied Animal Reproduction. $6^{\text {th }}$ ed. New Jersey: upper saddle River 193 - 194(2004).

10. Jackson, P. G. G. Handbook of veterinary obstetrics. $2^{\text {nd }}$ ed, Elsevier Sci Ltd.; pp: 17-29 (2004).

11. Noakes, D. E., Parkinson, T. J., England, G. C. W., and Arthur, G.H. Arthur's Veterinary Reproduction and Obstetrics. $8^{\text {th }}$ ed., Elsevier Sci. Ltd.; pp: 216222(2001).

12. Roberts, S. J. Veterinary obstetrics and genital diseases. $2^{\text {nd }}$ ed., Edwards brothers, Inc. Arbor, Michigan, USA(1971).

13. Saffert, A., Piper, G. and Jetten, J. Effect of package light transmittance on vitamin content of milk, part 3: fortified UHT low fat milk. Packaging Technology and Science, 22(1), 31-37 (2008).

14. Coles, E. H. Veterinary clinical pathology. $4^{\text {th }}$ ed., W.B. Saunders Company Philadelphia, London, Toronto. PP: 362-363 (1986).

15. Beaudeau, F., Ducrocq, V., Fourichon, C. and Seegers, H. Effect of Disease on Length of Productive Life of French Holstein Dairy Cows Assessed by Survival Analysis. Journal of Dairy Science, 78(1), 103-117(1995).https://doi. org/10.3168/jds.S0022-0302(95)76621-8

16. Silva, F. V., Souza, G. B., Ferraz, L. F.M., and Nogueira, A. R. A. Determination of chloride in milk using sequential injection automated conductimetry. Food Chemistry, 67(3), 317322(1999).https://doi.org/10.1016/S03088146(99)00122-3

17. Moore, D. S., McCabe, G. P., and Craig, B. A. Introduction to the Practice of Statistics. W.H. Freeman, New York, NY (2009).
18. Armstrong, R. A. When to use the Bonferroni correction. Ophthalmic Physiological Optics, 34, 502508(2014). http://doi.org/10.1111/opo.12131

19. Boucher, Z. Breed and diet effects on ewe colostrum quality, lamb birthweight and transfer of passive immunity. Bachelor dissertation (Honor). School of Animal and Veterinary Sciences, Faculty of Science, Charles Sturt University, Wagga Wagga, Australia (2014).

20. Fleenor, W. A. and Scott, G. H. Hydrometer test for estimation of immunoglobulin concentration in bovine colostrum. Journal of Dairy Science, 63,973-977(1980).https://doi.org/10.3168/jds. s0022-0302(80)83034-7

21. Sahan, N., Say, D., and Kacar, A. Changes in Chemical and Mineral Contents of Awassi Ewes Milk During Lactation. Turkish Journal of Veterinary and Animal Sciences, 29(3), 589593(2005).

22. Mohapatra, A., Shinde, A. K., and Singh, R. Sheep milk: A pertinent functional food. Small Ruminant Research.,181,6-11(2019).https://doi. org/10.1016/j.smallrumres.2019.10.002

23. Aernouts, B., Polshin, E., Lammertyn, J., and Saeys, W. Visible and near-infrared spectroscopic analysis of raw milk for cow health monitoring: Reflectance or transmittance? Journal of Dairy Science. 94(11), 5315-5329(2011).https://doi. org/10.3168/jds.2011-4354

24. Aernouts, B., Van Beer, R., Watte, R., Huybrechts, T., Lammertyn, J., and Saeys, W. Visible and nearinfrared bulk optical properties of raw milk. Journal of Dairy Science,98(10), 6727-6738(2015).https:// doi.org/10.3168/jds.2015-9630

25. Gastélum-Barrios, A., Soto-Zarazúa, G., EscamillaGarcía, A., Toledano-Ayala, M., Macías-Bobadilla G., and Jauregui-Vazquez, D. Optical Methods Based on Ultraviolet, Visible, and Near-Infrared Spectra to Estimate Fatand Protein in Raw Milk: A Review. Sensors, 20 (3356), 1-16(2020).https:// doi.org/10.3390/s20123356 
دَور التغيرات في الخصائص الفيزيائية والكيميائية للحليب في تحديد الولادة في النعاج

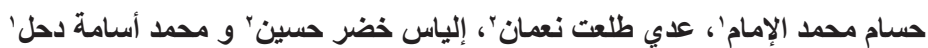

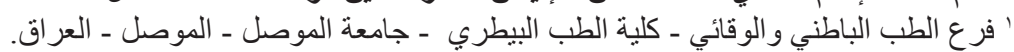

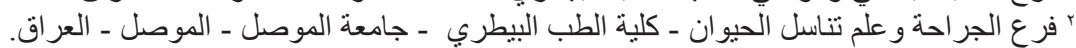

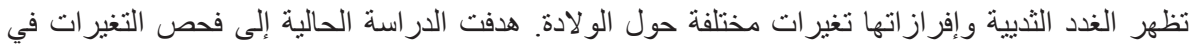

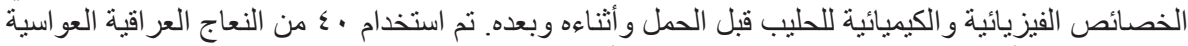

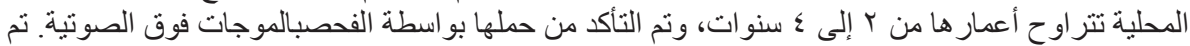

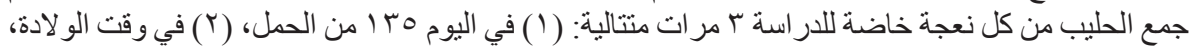

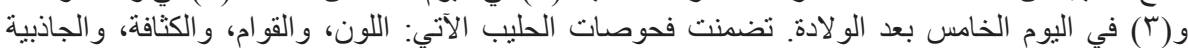

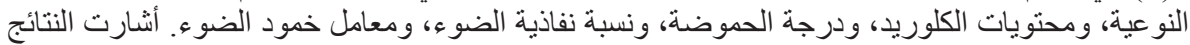

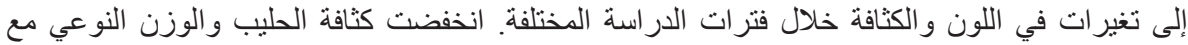

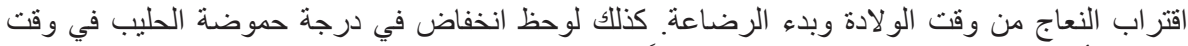

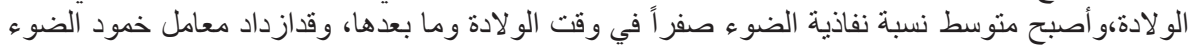

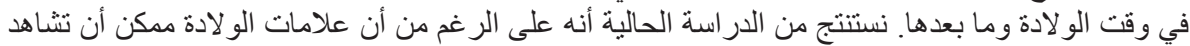

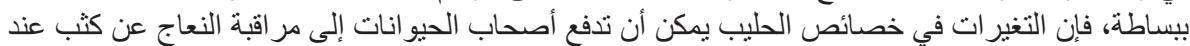

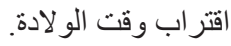

